\title{
The Role of Knowledge Management and Technological Innovation in the Performance of New Product Development: An Empirical Study of Pharmaceutical Industry in Jordan
}

\author{
Mohammad Abdelkareem Alraggad ${ }^{1} \&$ Mushera Adnan Onizat ${ }^{1}$ \\ ${ }^{1}$ The World Islamic Sciences \&Education University, Jordan \\ Correspondence: Mohammad Abdelkareem Alraggad, The World Islamic Sciences \&Education University, \\ Jordan. E-mail: Mohammadalraggad1953@gmail.com
}

Received: April 9, 2020

doi:10.5539/ijbm.v15n7p10
Accepted: May 20, 2020

Online Published: June 3, 2020

URL: https://doi.org/10.5539/ijbm.v15n7p10

\begin{abstract}
So far, firms are ignorant of actual implications of managing knowledge and technology innovation. So far, firms are ignorant of actual implications of knowledge management and technology innovation. This research investigated the role of managing knowledge and innovation technology in new product performance of Pharmaceutical Jordanian manufacturing firms. Data were gathered from 4 firms out of 15 companies by developed questionnaire. The Cronbach's Alpha was utilized to examine reliability, and multiple regressions analysis was conducted for hypothesis testing.

According to extant literature, a research frame was designed showing a positive correlations' among research constructs. Results of regression analysis reveal that knowledge management with (Knowledge creation and knowledge transfer) and technology innovation with (product innovation and process innovation) impact new product performance with its constructs. Results of regression analysis reveal that knowledge management and technology innovation effect new product performance. Results of this research may assist academics and managers in designing knowledge management programs to achieve higher technological innovations in product and process to develop new products performance through a successful financial and marketing performance. The study concludes and recommended to conduct further research.
\end{abstract}

Keywords: knowledge management (KM), technology innovation (TI), new product development (NPD), pharmaceutical manufacturing

\section{Introduction}

The pharmaceutical industry in Jordan enjoys high reputation and occupies a eminent position locally and globally alike, it is one of the essential of economy pillars, and is a leading consort in country's prosperity and development, as it significantly take part in to the gross domestic product and has an important share of the total national exports (Pharmaceutical Industry in Jordan, 2012). The Jordanian private sector, especially pharmaceutical and information and communication technologies (ICTs) has the ability to assist the economy in Jordan to fulfill higher outgrowth rates by innovation adoption and increasing production capacities (Obeidat, 2012).

In dynamic abilities approach that roots in resource-based on economy point view by Penzo (1959), the central function of strategic management are seemed (Amirhosein, 2018). Among these objectives, firm's (knowledge-based) resources, with respect to organizational innovation have attracted attention over the last decades (Acur, Kandemir,\& Boer, 2012). An increasing amount of research and studies on strategic management and innovation, knowledge was at the center of interests (Darroch, 2005). In innovation literature, knowledge is discussed as a significant component of recombination process to generate innovation in firms (Galunic \& Rodan, 1998; Amirhosein, 2018; Yung-Lung Lai et al., 2012). Knowledge has a deep - rooted value to be managed, created, applied, exploited and developed, shared, and transferred, and can be seen as resource that raises management's questions about traditional asset's as when, how much, and what to invest in. However, for any firm, knowledge has to be managed elaborately as needful intangible assets.

Firms are founded to stay, and projects of New Products Development (NPD) are fundamentally assessing firm's ability not only to market's share grow up, but also to boom in extremely competitive business environments. 
Thus, assessing elements that foresee new product performance is still remaining a great challenge encountering firms when they formulate, implement and assess their NPD strategies in order to fulfill NPD performance on one hand, and on the other hand at least identify the failure factors (Abdelqader, 2013; Amirhosein, 2018; Awad \& Akroush, 2016). Technological Innovation (Tech.I) is foremost concerned in evolution and new knowledge adoption that is incorporated into product or service and or process (Cooper, 1998). Therefore, this kind of invention is linked to company's core business functions, product process, and technologies utilized in developing new products as well service providing. Technology and knowledge considered as a main source of creating a competitive advantage and strategic assets (Yung-Lung Lai et al, 2012).

Upon a thorough review by the researcher of previous studies, it was noted that many of them explored the impact of Knowledge Management (KM) on the performance of developing new products (Abdelqader, 2013; Amirhosein, 2018; Yung-Lung Lai et al, 2012; Sylva Waribugo, 2016), or on the association between knowledge management and Tech.I (Gan, 2003; Carrillo \& Gaimon, 2004; Chou, 2004; Darooch, 2005). Yet, small number of studies have addressed the role of both knowledge management and Tech.I on new product innovation performance, also, there is no researches (as far as the researcher knows) on the role of KM and Tech.I in the pharmaceutical manufacturing, especially as it is a sector based on knowledge and technology as well as product innovation.

Therefore, with an increasing significance of KM and Tech.I for manufacturing sector in general, and for pharmaceutical manufacturing companies in particular, as well the lack of studies, this research conducted to bridge the gap in this arena. Hoping to verify and get new benefice results, and contribute to literature. Therefore, the objective of this research is to investigate the role of KM \&Tech.I in new product performance in pharmaceutical manufacturing firms in Jordan based on relevant literature and empirical verification; to know which types of Tech.I that they adopt; to understand whether KM processes actually can enhance the Tech.I; and to identify the NPD performance measures. The remainder of this research proceeds as follow: Section 2 presents the theoretical lens, section 3 presents the literature review for introducing key constructs \& hypotheses development, section 4 provides research methodology, section 5 expounds the empirical results and ends the research with conclusions.

\section{Theoretical Lens}

\subsection{Knowledge Management}

Nowadays, in the knowledge-based economy, managing knowledge has become the effective tool where firms' competes. The review of extant literature revealed that knowledge management is knowledge creation (KC) and knowledge transfer (KT) by organization's staff (Nonaka \& Takeuchi, 1995; Beckett, 2000), and knowledge disseminating, integrating, and accumulate that are utilized to construct efficient knowledge resources and features to earn optimum profitability (Amirhosein, 2018; Teece, 2000); Gold, Malhotra, and Segars, (2001) examined the issue of efficient from organizational capacities viewpoint, this view states that, knowledge structure including novel technology, well organizational culture, and structure besides the knowledge acquisition, transfer, application, and protection are critical organizational abilities, or a prerequisites for dynamic of managing knowledge.

Cui (2005), also declares that KM capacities includes three interconnected processes: knowledge acquisition; conversion; application (Gold, Malhotra \& Segars, 2001). Knowledge is not only a significant asset of organization, but also is a primary source of competitive edge (Gold, Malhotra, \& Segars, 2001; Grant, 1996). Thence, KM capacities refer to the KM processes that develop, and utilize knowledge within an organization (Gold, Malhotra, \& Segars, 2001). As mentioned in literature, several of KM definitions have been presented (Alavi \& Leidner, 2001; Davenport \& Prusak, 1998; Probst, Raub, \& Romhardt, 1999).

Many approaches to KM focused on the creation, transfer, dissemination, storage, and application of existing or new knowledge (Coombs \& Hull, 1998). Wiig (1997), assures on existing KM, and mentions that the aim of KM is to maximize the firm's knowledge relevant to efficiency, and returns from its knowledge assets, and to refresh them continually. KM contains of making knowledge seen and evolving an intense knowledge culture in organization (Davenport \& Prusak, 1998). While, many studies identified acquisition, identification, development, diffusion, usage, and storage of knowledge as an essence of KM processes (Alavi \& Leidner, 2001; Probst, Raub, \& Romhardt, 1999). Also Swan, Newell, and Scarbrough (1999), stated that knowledge exploration and exploitation are the core aims of KM. Yung-Lung Lai et al. (2012) stated that the creation, dissemination, combination, and transfer of knowledge are dynamic processes of KM.

According to Tidd, Bessant, and Pavitt (2001), KM implementation can be categorized into IT-based KM, human-resource-related KM, and process-based approaches. IT-based or (supply-driven KM) confirms the need 
for (easy) access to existing knowledge stored in databases, or elsewhere (Swan, Newell, \& Scarbrough, 1999). Gold, Malhotra and Segars (2001), investigated the issue of effective KM from organizational capabilities view, this perspective states that a knowledge infrastructure including technology, structure, and culture along with a knowledge process architecture of creation and acquisition, conversion, application, storage, and protection, and transfer are essential organizational capabilities or preconditions for effective KM. The results provide a basis to understand the competitiveness and innovativeness tendency of an organization as it enters a program of KM. Cui, Griffith, and Cavusgil, (2005), also mentioned that KM capabilities consist of three interrelated processes: knowledge creation and acquisition, knowledge conversion, and knowledge application and storage (Gold, Malhotra \& Segars, 2001). In contrast, the demand-driven approach is more concerned with facilitating interactive knowledge sharing, and knowledge creation (Swan, Newell, \& Scarbrough, 1999). Although there are still many classifications of $\mathrm{KM}$, this research addressed two dimensions of KM processes, these are: knowledge Creation (KC) and knowledge transfer (KT) as research variable.

\subsection{Technological Innovation}

Innovation, in particular the innovation of product and process became a corner stone in firms' successfulness (Alegre, Lapiedra, \& Chiva). As such, (Damanpour\& Gopalakrishnan, 2001); (Al-Khalil \& Dahiyat, 2014), Tech.I is categorized into: product/ service innovation, and process innovation. Product innovation (PTI) is fundamentally attentive to evolving new products so as to encounter customers' needs by concentrate on creating new generating a value, either by improving exist product or evolving a new innovative one (Damanpour, 1997). PTI is vitally significant for firms that are aims to acquire a wider market portion and new opportunities. The intense interact among organization's customer promotes providing propositions that can be advantageous in developing a novel product (Droge, Jayaram, \& Vickery, 2004).

Besides, the Process of innovation(PSI), is focused developing firm's / product and process operations via introducing new production techniques, practices, strategies, equipment's, processes, task features, and workflow techniques (Damanpour \& Gopalakrishnan, 2001; Damanpour, 1997; OSLO Manual, 1997; Oslo Manual, 2005). Unlike PTI, PSI concentrates on enhancing the outcomes and competency of organization's functional activities (Al-Khalil \& Dahiyat, 2014). PSI divided into organizational and Tech.I (OECD, 2005). Tech.I can be categorized into 3 components: tool, machine and automation (Gehlen, 1998; OECD, 2005). Jumson (1992) referred to technology as "the knowledge used in production process (Hargadon \& Andrew, 1997).

Therefore, this definition of Tech.I in this research is similar to the one suggested by OSLO Manual $(1997 ; 2005)$; OECD (2005); Amirhosein (2018); Yung-Lung Lai et al. (2012); Abdelqader (2013); Atuahene-Gima, (2007), that Tech.I, point out to product and process innovation or relevant operations via technology, encompasses of new products, functional procedures by the technology adopted, or generating products, procedures with fundamental improvements in technology. The research uses Tech.I types: Product Innovation (PTI) and Process Innovation (PSI) as research variables.

\subsection{New Product Development (NPD)}

Firms are founded to survive and ventures of New Products Development (NPD) are fundamentally an indicator the firm's capability not only to grow in the market, but also to prosper in highly competitive business environments (Abdelqader, 2013; Awad \& Akroush, 2016; Yung-Lung Lai et al., 2012; Yassine et al, 2003). Therefore, improving NPD performance is a primary driver for developing, fulfilling, and sustaining firm's competitive edge. Hence, changing business environment is the most significant driver for company to successful competes by developing and introducing new and innovative products at increasing rates (Awad \& Akroush, 2016). According to Chan and Ip (2011), NPD is seen as competitive weapons that assist firms to survive and succeed in dynamic markets. Therefore, Profitable new products play an important role not only in penetrating the markets, but also in building customer relationships, acquire new customers, maintaining them, and obtaining profits.

NPD includes the whole process of obtain a new product to the market; the basic aspect of it is designing, and requires an understanding of customer's needs and willingness, competitive environment, and market status. Using best practices, removing barriers, knowledge flow and communication are the main concerns of management to manage NPD. According to Martin (1996), NPD gets considerable profits to businesses if new product is introduced to the market at right time, reasonable priced, and targets a specific segments of customers. For an effective NPD there should be coordination between manufacturing, engineering, R\&D, marketing, finance and purchasing and marketing departments, and first has to test new product, and then a cross-functional team created to develop it (Kim, Park, \& Sawng, 2016). NPD performance measurement can be physical or intangible indicators (Cooper, 1994), so these measurements should integrate. However, based on relevant 
literature review and quantitative work findings, this research suggests 2 dimensions of NPD performance measures, namely, NPD marketing performance, and NPD financial performance.

\section{Literature Review\& Hypotheses Development}

Exploring the correlations between research variables is the objective of this section. In a knowledge based economy, Tech.I process lies in the company's technological knowledge resources (Gan, Pan,\& Chen, 2003). Innovation is the core formats of $\mathrm{KC}$, and through $\mathrm{KM}$ processes, when organization's inherent and exhibited knowledge react; innovation is the result (Nonaka \& Takeuchi, 1995). Also, Carrillo and Gaimon (2004), indicated KM is the only way to minimize uncertainty in technology systems changes. Previous researches indicate that KM can improve corporate performance, competitiveness, and promote innovation (Abdelqader, 2013; Yung-Lung Lai et al., 2012; Amirhosein, 2018). Knowledge is not only a key asset of an organization, but also is the essential source of competitive advantage and Tech.I (Gold, Malhotra, \& Segars, 2001), KM abilities refer to the KM processes such as knowledge creation and transfer that develop, and utilize knowledge within firm which led to push Tech.I operations.

Findings of Darroch, (2005); Yung-Lung Lai et al. (2012); Malkawi and Rumman, (2016) assures the positive role of knowledge dissemination, creation, and transfer on Tech.I. Successfulness. Another side of the relationship between $\mathrm{KM}$ and innovation is how different kinds of innovation (product and process innovation) are influenced by KM. Darrosh and MCnoughton, (2002) stated that the types of innovation require different resources, and thus a distinguished KM strategy upon their study on investigation the effects of KM on innovation types, their findings revealed that different KM activities are significant for different kinds of innovation including Tech.I. From the scholars cited above, new activities in firms must be based on how to manage knowledge, and rely on new knowledge at the same time; how apply KM to create or transfer which would of course, impact the performance of innovative activities. Therefore, it can be recognized that Tech.I and knowledge functions are highly correlated. Thus, the aforementioned discussion guided to propose the following hypothesis one (H1).

\section{Hypothesis One (H1): There is a positive and significant impact of KM on Tech.I.}

The main aim of KM is to conduct information interchange successfully in cost-effective methods, to cut short the time of NDP process. Awad and Akroush (2016) indicated that new product development seen as a process in which a chain of information processing activities are integrated to gain opportunities and market requirements into knowledge for production process. All of Nonaka and Takeuchi (1995); Abdelqader (2013); Amirhosein, (2018); Yung-Lung Lai et al. (2012) stated that executing knowledge management activities is an efficient method to enhancing new product development performance. Others argue that cross-functional teamwork, internal and external communication, inter-firm relationships, knowledge transfer are important factors that impact NPD performance success (Felekoglu, Maier, \& Moultrie, 2013). Tsai, Huang, and Tsai, (2013), reviewed the literature on NPD and examined ten market drivers of NPD that include market and customer orientation, competitor orientation, marketing synergy, product's feature, market's potential and turbulence, competitive strength, and launch proficiency. Awad and Akroush (2016), indicates that NPDFP was categorized as the most significant measure that Jordanian manufacturing companies use to evaluate the success of their new products.

In short, from above literature, it is known that NPD is indeed an environment of knowledge creation and transfer with staff in company working on the task of product development, increasing their sharing and interaction, extracting big need for different knowledge integrated activities. Thus, KM functions and NPD activities are correlated factors, thus, the following hypothesis two (H2) was formulated as follows:

\section{Hypothesis Two (H2): There is a positive and significant impact of KM on NPD performance.}

Technology rapid changes, and customers' preferences and desires compel companies to continually develop which enables it to push new products to the market. Thus, (Yung-Lung Lai et al., 2012) this will boost organization's learning as well shorten product time to be put on the market, and then increase the whole firm's profitability. Walsh and Linton (2002), shows that new product development would have a varied performance outcomes based on the different degree of Tech.I used in product performance in innovative products companies, the higher degree of Tech.I can supports the new product performance to the better. Petroni and Panciroli (2002), investigates the role of Tech.I capabilities in firms and stated that organization's innovation capacity has a positive significant impact firm product development, flexibility, and production's performance. Literatures reveals that Tech.I aspects are significant factors that impact the performance of new product development, therefore, the following hypothesis three (H3) was formulated as follows: 
Hypothesis Three (H3): There is a positive and significant impact Tech.I functions on NPD performance.

In accordance to KM, Tech.I, and NPD performance relations. Abdelqader, (2013) and Yassine et al. (2003) suggests that innovation is an operation by which new knowledge is executed to elevate firm capability, and then, developed new products to generate value. Nonaka and Takeuchi (1995) stated that innovation in firms often appear through knowledge staff and technology and knowledge to create and ascertain the concept for new product; then the product prototype is launched. Knowledge created through innovation processes is disseminated to a whole organization's different structures. Andrson (2003) suggested that the creation and transfer of managerial knowledge within organization can promote speed and ability of organization's Tech.I, and its quality. Elevation of Tech.I capacity can also improve the ability and speed of new product development performance by firms, thus, building competitive edge. In sum, literature shows that Tech.I, application of knowledge by firms are actually crucial elements that impact new product development performance. Accordingly, this research proposes that knowledge management, Tech.I, and new product development performance are correlated, thus the following hypothesis four (H4) was formulated as follows:

Hypothesis Four (H4): There is a positive and significant impact of KM and Tech.I on NPD performance.

\section{Research Method}

\subsection{Research Framework}

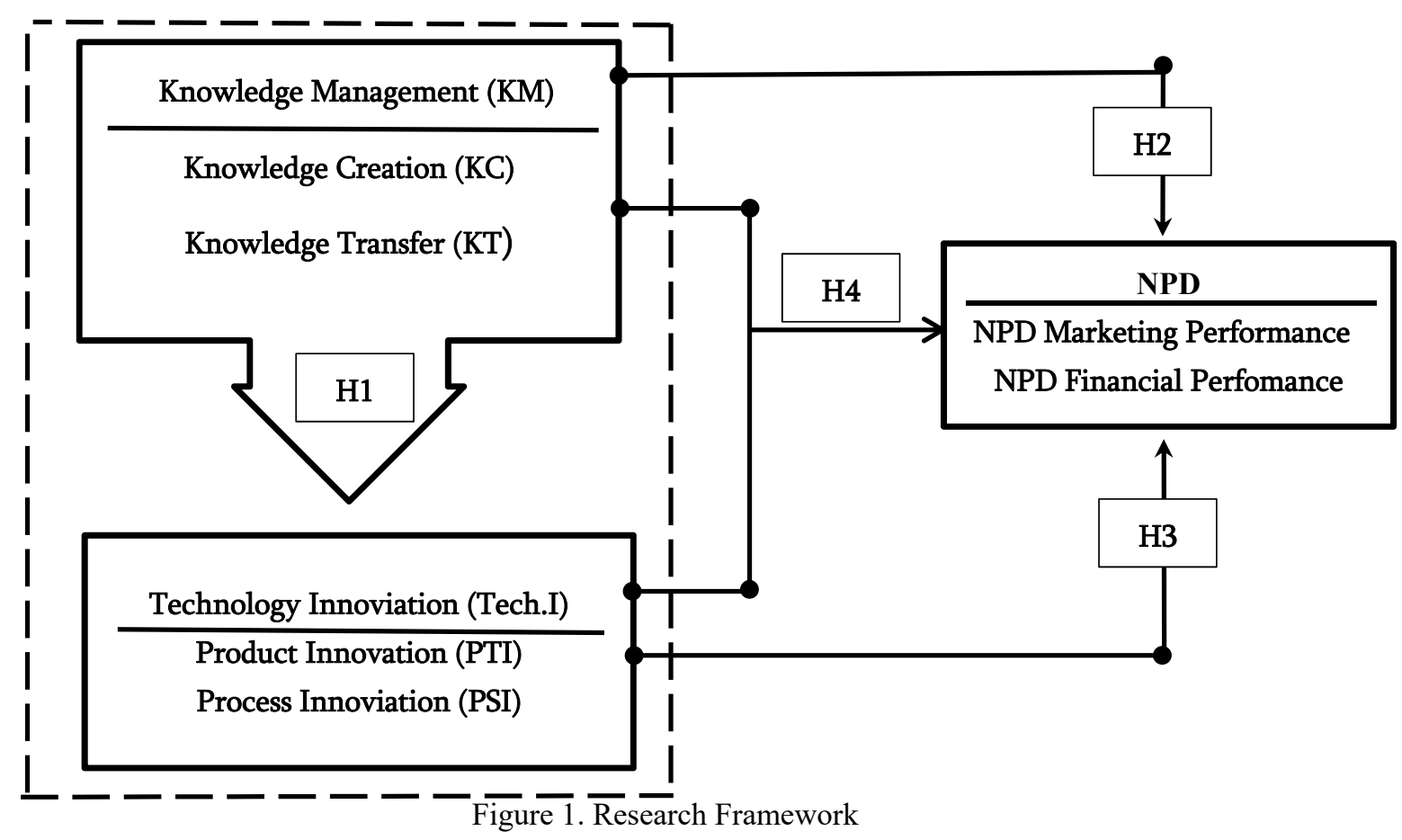

\subsection{Population \& Sample}

The research population encompassed all 15 pharmaceutical manufacture industry companies. The population has many advantages, since the Production, integration, application of intensive knowledge, technology, the creation of new products to acquire a market share, generate profit; marketing is the essence of the pharmaceutical industry. The sample was the 4 largest companies in size and industry registered in Amman Stock exchange. Data were collected from CEOs, senior manager's, IT staff, production managers, knowledge workers, R\&D staff through Stock exchange. Data were collected from CEOs, senior manager's, IT staff, production managers, knowledge workers, R\&D staff through developed questionnaire according to the purposes of this research based on theoretical lens and literature.

140 questionnaires were sent by e- mail, because of the consequences of COVID - 19 at the moment. 107 questionnaires were returned, 6 of them were neglected for not being completed, so there are 101 valid samples with $(72.1 \%)$ response rate. Moreover, taking into account the desire to fill out the questionnaire, number of items was depress as far as possible. Regarding items designing, 5 - point Likert scale was utilized the Likert 5 -point scale is utilized. 
The research variables' are determined as follows: Knowledge management dividing into two variables, $\mathrm{KC}$ and KT measured by 7 questions; Tech.I also dividing into two variables PTI and PSI measured by 8 questions; as for rating of the performance of new product development (NDP), dividing into two variables NPDMP, NPDFB measured by 6 questions.

\subsection{Variables Validity \& Composite Reliability}

The validity of research tool was evaluated through the pilot work with IT managers, production and marketing managers in targeted companies, and 6 experts' academics in Jordanian universities from college of engineering and business who checked the relevance and appropriateness of the tool to fulfill the research aims. So, there is a considerable degree of tool validity. In terms of reliability, this research utilizes statements analysis to delete non-influential, and uses principal component analysis to calculate the Cronbach's $\alpha$ value (Table 1), which all is more than $(0.70 \%)$, thus, there is considerable reliability. Analysis of correlations also depicted in Table 2.

Table 1. Reliability analysis of research constructs

\begin{tabular}{llllllll}
\hline Variable & KC & KT & PTI & PSI & NPD & NPDMP & NPDFP \\
\hline $\boldsymbol{\alpha}$ & 86.3 & 82.8 & 74.1 & 84.2 & 86.9 & 74.2 & 77.4 \\
\hline
\end{tabular}

\section{Results \& Conclusions}

Table 2 presents the means(M), standard deviations(SD) for each of three components, and Pearson's Correlation beween them.

Table 2. M, SD, \& Pearson's correlations

\begin{tabular}{|c|c|c|c|c|c|c|c|c|c|}
\hline Variable & $\mathbf{M}$ & SD & KC & KT & PTI & PSI & NPD & NPDMP & NPDFP \\
\hline $\mathrm{KC}$ & 3.245 & 0.712 & 1.000 & & & & & & \\
\hline KT & 3.379 & 0.620 & $0.471^{* * *}$ & 1.000 & & & & & \\
\hline PTI & 3.588 & 0.631 & $0.312^{* *}$ & $0.449^{* * *}$ & 1.000 & & & & \\
\hline PSI & 3.524 & 0.658 & $0.624^{* * *}$ & $0.438^{* * *}$ & $0.400^{* * *}$ & 1.000 & & & \\
\hline NPD & 3.390 & 0.705 & $0.574^{* * *}$ & $0.523^{* * *}$ & $0.421^{* * *}$ & $0.539 * * *$ & 1.000 & & \\
\hline NPDMP & 3.637 & 0.639 & $0.613^{* * *}$ & $0.391^{* * *}$ & $0.449^{* * *}$ & $0.495^{* * *}$ & $0.352^{* * *}$ & 1.000 & \\
\hline NPDFP & 3.501 & 0.621 & $0.279^{* * *}$ & $0.459^{* * *}$ & $0.478^{* * *}$ & $0.637^{* * *}$ & $0.551^{* * *}$ & $0.617 * * *$ & 1.000 \\
\hline
\end{tabular}

Note. $* \mathrm{P}<0.05, * * \mathrm{P}<0.01, * * * \mathrm{P}<0.001(\mathrm{n}=101)$.

\subsection{Test of Hypotheses}

The research hypotheses was verified by regressing, KM to Tech.I and NPD perfprmance, and of KM,Tech.I to NPD performance. Table $3 \&$ Table 4 , presents the results of multiple regression analysis. To predict the goodness-of fit of the models, the multiple correlation coefficient $(\mathrm{R})$, coefficient of determination $\left(\mathrm{R}^{2}\right)$, and $\mathrm{F}$ ratio were examined.

Hypothesis One (H1): There is a positive and significant impact of KM on Tech.I.

Hypothesis Two (H2): There is a positive and significant impact of KM on NPD performance

Table 3. Regression analysis Model 1: KM $\longrightarrow$ (Tech.I \& NPD performance)

\begin{tabular}{|c|c|c|c|c|c|c|}
\hline Variable & Tech.I & PTI & PSI & NPD & NPDMP & NPDFP \\
\hline Constant & 0.997 & 0.977 & 0.801 & 1.560 & 2.401 & 1.214 \\
\hline $\mathrm{KC}$ & $0.419^{* * *}$ & $0.485 * * *$ & $0.240^{*}$ & $0.441^{* * *}$ & $0.252^{*}$ & $0.332^{* *}$ \\
\hline KT & $0.300 * *$ & 0.192 & $0.374^{* * *}$ & $0.441^{* * *}$ & $0.252 *$ & $0.324^{* *}$ \\
\hline $\mathrm{F}$ & $41.890^{* * *}$ & $30.496^{* * *}$ & $12.835^{* * *}$ & $18.381^{* * *}$ & $4.239^{* * *}$ & $27.023^{* * *}$ \\
\hline $\mathrm{R}$ & 0.774 & 0.424 & 0.294 & 0.346 & 0.115 & 0.459 \\
\hline $\mathrm{R}^{2}$ & 0.599 & 0.180 & 0.090 & 0.120 & .013 & 0.211 \\
\hline Sig & 0.000 & 0.001 & 0.002 & 0.000 & 0.001 & 0.000 \\
\hline
\end{tabular}

Note. $* P<0.05, * * P<0.01, * * * P<0.001$. 
In table 3, results show that, $\mathrm{R}$ of independent variable $\mathrm{KM}$ on the dependent variable Tech.I is 0.774 , which indicates that KM has a positive and high association with Tech.I and NPD performance. the $\mathrm{R}^{2}=0.599$, suggesting that $59.9 \%$ of the variation in Tech.I and NPD performance was explained by the KM dimensions(KT, $\mathrm{KC})$, the $\mathrm{F}$ ratio, had a value of $41.890,(\mathrm{sig}=0.000)$ and was considered significant.

Coefficients in model 1. PTI, PSI, NPD are also significant (0.001, 0.002, and 0.000), which means KM has a significant positive impact on PTI, PSI. Eventually, results of multiple regression analysis pointout that there is positive and has a significant impact of KM on Tech.I, thus, H1 is supported. Likewise, the coefficients NPD, NPDMP, and NPDFP reach significant impact $(0.000,0.001,0.000)$, which means that there is linear relationship between KM and NPD performance including (NPDMP and NPDFP) is significant, thus, H2 is supported also.

\section{Hypothesis Three (H3): There is a positive and significant effect of Tech.I functions on NPD performance}

Hypothesis Four (H4): There is a positive and significant impact of KM and Tech.I on NPD performance

Results in table 4 show that, $\mathrm{R}$ is 0.738 , which indicates that Tech.I functions has a positive and high association with NPD performance. The $\mathrm{R}^{2}=0.544$, suggesting that $54.4 \%$ of the variation in NPD performance was explained by the dimensions of Tech.I (PTI and PSI, the F ratio, had a value of 40.165 , $(\mathrm{sig}=0.000)$ and was considered significant. Also,the coefficients in model 2, NPD, PTI, and PSI also reach a significant levels $(0.000$, $0.001,0.002)$, which means Tech.I functions has a significant positive effect on NPD performance including NPDMP and NPDFP. In conclusion, the results of multiple regression analysis indicate that there is a positive and significant impact of Tech.I, functions on NPD performance, thus H3 is supported.

Likewise, the coefficients also have reached significant impacts, which means that the linear relationship between KM, Tech.I and NPD performance is significant, and has a significant positive impact on aspects of NPD performance, NPDMP \& NPDFP, so, the hypothsis (H4) was supported.

Table 4. Regression analysis model 2 ( KM, Tech.I) $\rightarrow$ NPD performance

\begin{tabular}{lllllll}
\hline Variable & NDP & PTI & PSI & NPD & NPDMP & NPDFP \\
\hline Constant & 0.737 & 0.425 & 0.440 & 0.849 & 0.393 & 0.476 \\
KC & & & 0.179 & -0.091 & -0.076 & -145 \\
KT & & & 0.023 & $0.259^{* * *}$ \\
PTI & 0.144 & 0.011 & 0.004 & 0.099 & $0.224^{*}$ & $0.279^{* *}$ \\
PSI & $0.249^{* *}$ & $0.480^{* * *}$ & $0.439^{* * *}$ & $0.495^{* * *}$ & $23.015^{* * *}$ & $12.977^{* * *}$ \\
F & 40.165 & $13.721^{* * *}$ & $22.249^{* * *}$ & 21.939 & 0.599 & 0.430 \\
R & 0.738 & 0.304 & 0.413 & 0.580 & 0.359 & 0.185 \\
R & 0.544 & 0.092 & 0.171 & 0.336 & 0.000 & 0.000 \\
Sig & 0.000 & 0.001 & 0.000 & 0.021 & & \\
\hline
\end{tabular}

Note. $* \mathrm{P}<0.05, * * \mathrm{P}<0.01, * * * \mathrm{P}<0.001$.

\subsection{Conclusions}

The aim of this research is to investigates the correlation between constructs: knowledge management (KM), Tech.I and NPD performance in pharmaceutical industry. This section discusses the key findings and implications, based on empirical analysis results. With respect to KM, Tech.I, variables, $\mathrm{KC}$ and $\mathrm{KT}$ in the KM dimensions have a significant impact on Tech.I, including PTI and PSI. This shows that in KM processes, KC \& KT are correlated with Tech.I as results of empirical research evidenced. This is supported by (Yung-Lung Lai et al., 2012; Malkawi and Rumman; Al-Khalil \& Dahiyat, 2014; Amirhosein, 2018), they stated that an effective managing KC \& KT within firms can promote firm's functions and Tech.I quality.

Also the findings of (Sylva Waribugo , 2016)(Sylva Waribugo, 2016), showed that all the dimensions of KM influenced product and process innovation of Manufacturing firms. Further Nonaka and Takeuchi (1995) emphasized that innovation types is the fruit of KM processes.Thus, pharmaceutical companies should well mangage $\mathrm{KM}$ functions $(\mathrm{KC}, \mathrm{KT}$ ) to innoviate new products or develop existing ones. That is, $\mathrm{KC}$ and transfer is correlated to the development of a new product in KM processes.

With respect to Tec.I \& NPD performance, PTI, and PSI has a significant impact on new product developmeny(NPD) performance including NPD financial perfomance,and NPD marketing performance. This result is consistent with the point of view (Yung-Lung Lai et al., 2012; Sylva Waribugo, 2016). The innovative technology in product and the process will improv NPD performance. This is consistent with the study by (Walsh 
\& Linton, 2002) (Walsh \& Linton, 2002) in manufacturing product firms; higher levels of technology innovation are useful for better performance by new products. This is consistent with (Guan et al, 2006)(Guan et al, 2006), the refinement in technology innovation can perform competitiveness and organization's better performance. Moreover, the results showed that new product performance (NPD) marketing performance success and NPD financial performance success has a significant impact on the performance of new product developing, this is consistent with (Awad \& Akroush, 2016; Awwad, 2011) findings.

On the whole, regression analysis of empirical research findings show that, KM capabilities as well as utilized levels of technology would impact NPD performance, which comply with (Sylva Waribugo, 2016; Afuah, 1998; Amirhosein, 2018). This was also confirmed by (Anderson, 2003) that the knowledge creation and transfer by firms can boost technological innovation in firm. This will boost process speed and product quality, and in turn obtain to NPD performance success.

Therefore, it was concluded that suitable KM through creation, and transfer of knowledge has a positive impact on NPD performance of pharmaceutical industry in Jordan. Based on research findings, the following recommendations are presented: (1) managers should take practical steps to facilitate all knowledge management activities including proper design to the latest technology to enhance knowledge conversion processes in to new innovative product; (2) the role of knowledge management in innovation remains obscure, so further research is required in this area.

\section{References}

Abdelqader, M., Abu, Q. M., \& Al Sakarneh, B. (2013). Impact of knowledge management and innovation on performance. Baghdad collage journal for economic sciences, 34.

Abdul Kareem Awwad Dr. Mamoun N. Akroush, (2016). New product development performance success measures: an exploratory research. EuroMed Journal of Business, 11(1), 2-29. https://doi.org/10.1108/EMJB-12-2014-0043

Acur, N., Kandemir, D., \& Boer, H. (2012). Strategic alignment and new product development: drivers and performance effects. Journal of Product InnovationManagement, 29(2), 304-318. https://doi.org/10.1111/j.1540-5885.2011.00897.x

Alavi, M., \& Leidner, D. E. (2001). Review: KM and KM Systems: Conceptual Foundations and Research Issues. MIS Quarterly, 25(1), 107-136. https://doi.org/10.2307/3250961

Alegre, J., Lapiedra, R., \& Chiva, R. (2005). A literature-based innovation output analysis: implications for innovation capacity. International Journal of Innovation Management, 9(4), 385-399. https://doi.org/10.1142/S1363919605001319

Al-Khalil, S. S., \& Dahiyat, S. E. (2014). Intellectual Capital Development and its Effect on Technical Innovation in Banks Operating in Jordan. Journal of Management Research, 6(1), 211-238. https://doi.org/10.5296/jmr.v6i1.4629

Amirhosein, M., Saghi, N., Mahmoud, M., \& Mohammad, D. (2018). The Relationship between Knowledge Management and Innovation Performance. Journal of High Technology Management Research, 29, 12-26. https://doi.org/10.1016/j.hitech.2018.04.002

Andrson, U. (2003). Managing the transfer of capabilities within multinational corporations: The dual role of the $\begin{array}{llll}\text { subsidiary. Scandinavian Journal of } & \text { Management, }\end{array}$ https://doi.org/10.1016/S0956-5221(03)00040-X

Atuahene-Gima, K. (1995). An exploratory analysis of the impact of market orientation on new product performance: A contingency approach. Journal of Product Innovation Management, 12(4), 275-293. https://doi.org/10.1111/1540-5885.1240275

Awwad, S. (2011). The influence of tactical flexibilities on the competitive advantage of a firm: an empirical study on Jordanian industrial companies. International Journal of Business and Management, 6(1), 45-60. https://doi.org/10.5539/ijbm.v6n1p45

Beckett, A. J., Wainwright, C. E. R., \& Bance, D. (2000). Knowledge management: strategy or software? Management Decision, 601-606. https://doi.org/10.1108/00251740010357221

Carrillo, J. E., \& Gaimon, C. (2004). Managing knowledge-based resource capabilities under uncertainty. Management Science, 1504-1518. https://doi.org/10.1287/mnsc.1040.0234

Chan, S. L., \& Ip, W. H.(2011). Adynamicdecisionsupportsystemtopredictthevalueofcustomer for new product 
development. Decision Support Systems, 52(1), 178-188. https://doi.org/10.1016/j.dss.2011.07.002

Coombs, R., \& Hull, R. (1998). Knowledge management practices and path - dependency in innovation. Research Policy, 27, 237-253. https://doi.org/10.1016/S0048-7333(98)00036-5

Cooper, J. (1998). A multidimensional approach to the adoption of innovation. Management Decision, 36(8), 493-502. https://doi.org/10.1108/00251749810232565

Cui, A. S., Griffith, D. A., \& Cavusgil, S. T. (2005). The influence of competitive intensity and market dynamism on knowledge management capabilities of MNC subsidiaries. Journal of International Marketing, 13(3), 32-53. https://doi.org/10.1509/jimk.13.3.32

Damanpour, F. (1997). Organizational Innovation: A Meta-Analysis of Effects of Determinants and Moderators. Academy of Management Journal, 34(3), 555-590. https://doi.org/10.5465/256406

Damanpour, F., \& Gopalakrishnan, S. (2001). The Dynamics of the Adoption of Product and Process Innovations in Organization. Journal of Management Studies, 38(1), 45-66. https://doi.org/10.1111/1467-6486.00227

Darroch, J. (2005). Knowledge management, innovation and firm performance. Journal of Knowledge Management, 9, 101-115. https://doi.org/10.1108/13673270510602809

Darroch, J., \& McNaughton, R. (2002). Examining the link between knowledge management practices and types of innovation. Journal of intellectual capital, 3(3), 210-222. https://doi.org/10.1108/14691930210435570

Davenport, T. H., \& Prusak, L. (1998). Working knowledge: How organizations manage what they know.

Droge, C., Jayaram., J., \& Vickery, S. K. (2004). The effects of internal versus external integration practices on time-based performance and overall firm performance. Journal of Operations Management, 22(6), 557-573. https://doi.org/10.1016/j.jom.2004.08.001

Felekoglu, B.,Maier, A. M., \& Moultrie, J. (2013). Interactions in new product development: how the nature of the NPD process influences interaction between teams and management. Journal of Engineering and Technology Management, 30(4), 384-401. https://doi.org/10.1016/j.jengtecman.2013.08.004

Galunic, D. C., \& Rodan, S. (1998). Resource recombination in the firm: knowledge structures the potential for Schumpeterian innovation. Strategic Management Journal, 19, 1193-1201. https://doi.org/10.1002/(SICI)1097-0266(1998120)19:12<1193::AID-SMJ5>3.0.CO;2-F

Gan, L. M., Pan, H., Liu, J. J. (2003). Studies in technological knowledge management of the corporation. Studies in Science of Science, 21(2), 15-22.

Gehlen, A. (1987). Man in the age of technology. New York: Colombia University Press.

Gold, A. H., Malhotra, A., \& Segars, A. H. (2001). Knowledge Management: An Organizational Capabilities Perspective. Journal of Management Information Systems, 18(1), 185-214. https://doi.org/10.1080/07421222.2001.11045669

Grant, R. M. (1996). Towards Knowledge - based theory of the firm. Strategic Management Journal, 17, 109-122. https://doi.org/10.1002/smj.4250171110

Guan, J. C., Yam, R. C. M., Mok, C. K., \& Ma, N. (2006). A study of the relationship between competitiveness and technological innovation capability based on DEA Models. European Journal of Operational Research, 170, 971-986. https://doi.org/10.1016/j.ejor.2004.07.054

Hargadon, A. (1997). Technology brokering and innovation in a product development firm. Administrative Science Quarterly, 42(4), 716-749. https://doi.org/10.2307/2393655

Kim, Y. H., Park, S. W., \& Sawng, Y. W. (2016). Improving new product(NPD) process by analyzing failure cases. Asia Pacific Journal of Innovation and Entreneurship, 10(1), 134-150. https://doi.org/10.1108/APJIE-12-2016-002

Koskinen, K. U., Pihlanto, P., \& Vanharanta, H. (2003). Tacit knowledge acquisition and sharing in a project work context. International Journal of Project Management, 281-290 https://doi.org/10.1016/S0263-7863(02)00030-3

Lai, Y. L., \& Lin, F. J. (2012). The Effects of Knowledge Management and Technology Innovation on New Product Development Performance: An Empirical Study of Taiwanese Machine Tools Industry. Procedia Social and Behavioral Sciences, 40, 157-164.

Malkawi, M. S., \& Rumman, A. H. B. (2016), Knowledge Management Capabilities and Its Impact on Product 
Innovation in SME's. International Business Research, 9(5), 76-85. https://doi.org/10.5539/ibr.v9n5p76

Martin. (1996). New Product Development. British Food Journal, 98(7), 1-35 https://doi.org/10.1108/0007070X199600001

Nonaka, I., \& Takeuchi, H. (1995). The Knowledge Creating Company. New York, NY: Oxford University Press.

OECD, O. M. (2005a). Guidelines for Collecting and Interpreting Innovation Data. Paris, France: Organization for Economic Cooperation and Development (OECD). https://doi.org/10.1787/9789264013100-en

OECD, O. M. (2005b). The Measurement of Scientific and Technological Activity.

Omar, O. (2014). Pharmaceutical industry, ICT can boost Jordan's economic growth. The Jordan Times. Retrieved

from http://www.jordantimes.com/news/business/pharmaceutical-industry-ict-can-boost-jordans-economic-growt $\mathrm{h}$

Petroni, A., Panciroli, B. (2002). Innovation as a determinant of suppliers' roles and performances: an empirical study in the food machinery industry. European Journal of Purchasing \& Supply Management, 8, 135-149. https://doi.org/10.1016/S0969-7012(02)00004-7

Swan, J., Newell, S., Scarbrough, H., \& Hislop, D. (1999). Knowledge management and innovation: Networks and networking. Journal of Knowledge Management, 3, 262-275. https://doi.org/10.1108/13673279910304014

Sylva, W., Ofoegbu, C., Wilson, A., \& Ekom, E. (2016).The Impact of Knowledge Management on Product Innovation of Manufacturing Firms in Nigeria. Journal of Information \& Knowledge Management, 6(6), 78-87.

Teece, D. J. (2000). Strategies for managing knowledge assets: the role of firm structure and industrial context. Long Range Planning, 33, 35-54. https://doi.org/10.1016/S0024-6301(99)00117-X

Tidd, J., Bessant, J., \& Pavitt, K. (2005). Managing innovation: Integrating technological, market and organizational change.

Tsai, K., Huang, C., \& Tsai, M. (2013). Reviews of market drivers of new product performance. International Journal of Market Research, 55(5), 719-738. https://doi.org/10.2501/IJMR-2013-058

Wiig, K. M. (1997). Knowledge management: where did it come from will it go? Expert Systems Applications, 13, 1-14. https://doi.org/10.1016/S0957-4174(97)00018-3

Yassine, A., Joglekar, N., Braha, D., Eppinger, S., \& Whitney, D. (2003). Information hiding in product development: The design churn effect. Research in Engineering Design, 14(3), 131-144. https://doi.org/10.1007/s00163-003-0036-2

\section{Copyrights}

Copyright for this article is retained by the author(s), with first publication rights granted to the journal.

This is an open-access article distributed under the terms and conditions of the Creative Commons Attribution license (http://creativecommons.org/licenses/by/4.0/). 